\title{
Ponowne spojrzenie na biografię Júlii Rajk
}

Andrea Pető

TEKSTY DRUGIE 2019, NR 1, S. 257-269

DOI: 10.18318/td.2019.1.17 | ORCID: 0000-0002-7525-2582

$\mathbf{T}$ Try lata mojego życia, między 1998 a 2001 rokiem, poświęciłam na opisanie historii Júlii Rajk. Zdecydowałam się zająć jej życiem ze względu na dwa nazwiska skazane na zapomnienie na Węgrzech w okresie powojennym (1949-1989). Po egzekucji noszących je osób, zostały wymazane z dokumentów, fotografii i historii. Znajomi bali się więzienia i egzekucji za mówienie o nich głośno. Pierwsze z tych nazwisk to László Rajk (19091949), który został rehabilitowany, jego ponowny pogrzeb odbył się 6 października 1956 roku, na krótko przed wybuchem Powstania Węgierskiego (23 października). Drugie nazwisko to Imre Nagy (1896-1958), premier w czasie Powstania, który został stracony w 1958 roku, z rozkazu Jánosa Kádára (1912-1989). Milan Kundera napisał, że walka człowieka z władzą jest walką pamięci z zapomnieniem. W historii Węgier w XX wieku nie było nikogo, kto walczyłby z oficjalnymi wersjami zapominania $\mathrm{z}$ takim zapałem jak Júlia Rajk. Musiała stoczyć walkę z zapomnieniem o nazwisko swojego męża, syna i własne. Rajk walczyła z zaciekłością i odwagą o ponowny pogrzeb
Andrea Pető profesorka na Wydziale Gender Studies w Central European University w Budapeszcie i doktorka nauk w Węgierskiej Akademii Nauk. W 2005 została nagrodzona Orderem Zasługi przez prezydenta Węgier a w 2006 - nagrodą Bolyai Węgierskiej Akademii Nauk. W 2018 uhonorowano ją nagrodą Europejskich Akademii imienia Madame de Staël za zasługi dla kultury. 
i rehabilitację dwóch mężczyzn, których nazwiska są teraz w każdym podręczniku historii. Jej nazwiska jednak wciąż tam nie ma. Została zapomniana nie tylko dlatego, że była kobietą. Do 1989 roku nie była w wystarczającym stopniu komunistką a potem - wypadła z kanonu, bo była zbyt komunistyczna. Jest to dobry powód, aby opisać jej życie, i liczyć, że w ten sposób uda się ją wpisać w historię.

Moja książka poświęcona jej życiu została opublikowana po węgiersku, niemiecku i bułgarsku'.

Opublikowałam także dwa recenzowane artykuły oparte na monografii - po angielsku i francusku. Zostałam też zaproszona do współudziału w tworzeniu wydawnictwa poświęconego historii kobiet podczas komunizmu i książki o procesie destalinizacji ${ }^{2}$. Te dwa tematy stanowią ramę dla historii Júlii Rajk i sygnalizują nową przestrzeń do szerszej dyskusji o tym jak ważne są kobiety z Europy Środkowej.

Pisanie książki było emocjonalnym wyzwaniem, jako że miałam do czynienia z historią o zdradzie, inwigilacji, przemocy i śmierci. Podczas pracy nad książką przeprowadziłam serię wywiadów z jedynym synem Júlii Rajk, László Rajkiem (ur. 1949). Po ostatnim wywiadzie powiedziałam mu, że planuję zakończyć pracę nad tekstem, ponieważ chcę już opuścić jego życie - tak szybko jak to możliwe. Uśmiechnął się gorzko i stwierdził, że teraz wiem,jak on myśli o sobie samym. Ten uśmiech był dla mnie ważny - przypomniał mi podczas pisania, że nie mogę do końca wniknąć w historię i zrozumieć uczucia bohatera. W dodatku zmiany, jakie przez ostatnie piętnaście lat zaszły w historiografii o kobietach, dowodzą jak bardzo się myliłam, myśląc, że mogę opuścić życie Júlii Rajk. W tym artykule omówię możliwe ramy narracyjne w opisie życia komunistycznych kobiet i w jaki sposób nałożenie różnych ram sprawia, że historia życia Júlii Rajk staje się niedostrzegana. Opiszę też, jakie zmiany zaszły w materiale źródłowym i w ramach narracyjnych w ciągu piętnastu lat, które minęły, odkąd wysłałam korekty, licząc, że zakończyłam pracę nad książką. Biograf/biografistka na zawsze pozostaje „wewnątrz” biografii

1 Po węgiersku: Rajk Júlia, Balassi, Budapest 2001, po niemiecku: Geschlecht, Politik und Stalinismus in Ungarn. Eine Biographie von Júlia Rajk. Studien zur Geschichte Ungarns, Bd. 12 (Gabriele Schäfer Verlag, Herne 2007), po bułgarsku: Julia Rajk (Altera. Sofia 2010).

2 Są to rozdziały: De-Stalinisation in Hungary from a Gendered Perspective: The Case of Julia Rajk, De-Stanising Eastern Europe. The Rehabilitation of Stalin's Victims after 1953, ed. by K. McDermott, M. Stibbe (Palgrave Macmillan, Basingstocke2015), s. 46-67, Hongrie 1956, Julia Rajk ou le pouvoir de deuil " "Clio. Femmes, Genre, Histoire” 2015 No. 1, s. 153-165, Hungary 1956: Júlia Rajk or the power of mourning , "Clio. Women. Gender History" 2015 No. 1, s. 153-164. 
swojej bohaterki, zawsze śledzi dalsze jej losy i stawia jako punkt odniesienia, ale bez iluzji, że całkowicie ją rozumiemy.

\section{Júlia Rajk, biografia napisana w 2001}

Była tylko jedna kobieta w historii Węgier, której przyszło mieć jako osobistych wrogów dwóch najbardziej wpływowych węgierskich polityków okresu powojennego - Mátyása Rákosiego (1892-1971) i Jánosa Kádára. To oni zaplanowali egzekucję jej męża po pierwszym węgierskim procesie pokazowym w 1949 roku. László Rajk, legendarny uczestnik hiszpańskiej wojny domowej, lider rodzimego ruchu komunistycznego na Węgrzech, minister spraw wewnętrznych sprawujący władzę żelazną ręką. Jedną z jego decyzji był dekret zakazujący działalności organizacji kobiecych na Węgrzech ${ }^{3}$.

Júlia Rajk urodziła się jako Júlia Földes w 1914 roku w rodzinie należącej do niższej klasy pracującej z silną tradycją komunistyczną. W latach 30. przez jakiś czas mieszkała w Paryżu, aktywnie działając dla promocji Czerwonej Pomocy dla Hiszpanii. Powróciła na Węgry na początku II wojny światowej. Ratowała życie komunistom żydowskiego pochodzenia, używając fałszywych papierów. Nielegalnie pracowała dla partii komunistycznej, w grudniu 1944 roku została aresztowana razem z partnerem, nad którym sprawowała opiekę z ramienia partii. Był nim lider nielegalnego ruchu komunistycznego na Węgrzech, László Rajk. Przydzielanie komunistkom przez partię roli opiekunek ważnych towarzyszy było powszechne, niezależnie od ideologii emancypacyjnej. Między 1945 a 1949 rokiem Júlia Rajk, jako żona słynnego ministra spraw wewnętrznych, należała do partyjnej elity. W tym okresie pani Rajk (znana na Węgrzech jako Rajk Lászlóné4), została także jedną z liderek w kontrolowanym przez komunistów Demokratycznym Związku Węgierskich Kobiet (MNDSZ). Rajkowie prowadzili życie zapracowanej pary. Júlia z radością oczekiwała narodzin dziecka, które przyszło na świat w styczniu 1949 roku. Ojcem chrzestnym László Juniora został János Kádár. Później zastąpił Rajka na stanowisku ministra spraw wewnętrznych, a ten został przeniesiony na mniej ważne stanowisko ministra spraw zagranicznych - Węgry były krajem, który nie prowadził polityki zagranicznej, a miał jedynie przyjacielskie

3 Na ten temat: A. Pető Women in Hungarian Politics 1945-1951, Columbia University Press, East European Monographs Series, New York 2003.

4 Na Węgrzech kobiety, zawierając małżeństwo, mają możliwość przyjąć nie tylko nazwisko męża, ale także i jego imię (z końcówką -ne) [przyp. tłum.] 
stosunki ze Związkiem Radzieckim. László Rajk nie był rusofilem, nawet nie mówił po rosyjsku, więc nie miał podstaw do utrzymania się na tym stanowisku i w ten sposób stał się idealnym kandydatem na pierwszą ofiarę stalinowskich procesów pokazowych na Węgrzech.

Po egzekucji męża Júlia Rajk została skazana na pięć lat więzienia za wspieranie - jak to określano - „wywrotowej polityki”. Jej proces odbył się w marcu 1950 roku, 9 miesięcy po aresztowaniu. Syn Júlii i László miał 5 miesięcy, gdy w czerwcu 1949 roku aresztowano jego matkę. Został zabrany do sierocińca, gdzie zmieniono mu imię i nazwisko na popularne na Węgrzech István Kovács.

Po odbyciu kary Júlia Rajk została wypuszczona na wolność jako Lászlóné Györk (pani László Györk). Nazwisko jej i syna zostało zmienione bez żadnej konsultacji - nazwisko Rajk miało zostać zapomniane. Swoje apele o oficjalną rehabilitację do władz partyjnych podpisywała oboma nazwiskami - Rajk i Györk. Była pewna, że jej mąż musi zostać rehabilitowany - uznany za ofiarę stalinowskiego procesu pokazowego w 1949 roku. W roku 1955, podczas procesu rehabilitacyjnego zażarcie walczyła, aby używać własnego nazwiska - pani László Rajk.

Rajk wykorzystywała jako swoją moralną przewagę fakt, że była wdową po niewinnie skazanym bohaterze węgierskiego ruchu komunistycznego, aby wymóc na kierownictwie partii rozpoczęcie i doprowadzenie do końca rehabilitacji więźniów politycznych. Jej mąż został pochowany z wszystkimi honorami 6 października 1956 roku. Zdjęcie wdowy i jej syna wykonane w czasie pogrzebu stało się sławne na świecie jako symbol ofiar stalinizmu.

"Język żałoby" jest przede wszystkim językiem kobiet - to dodało Rajk pewności siebie. Walka o pamięć o jej rozstrzelanym mężu nadała znaczenie jej latom w więzieniu. Jako żona walcząca o godny pochówek dla męża była ponad kontrowersje i linie podziału w węgierskiej polityce. Fotografia z cmentarza Kerepesi ${ }^{5}$ w Budapeszcie przedstawiająca Júlię Rajk z synem podczas ponownego pogrzebu jej męża ukazała się w międzynarodowej prasie. To nie był jednak koniec walki. Przyszli liderzy powstania węgierskiego zobaczyli, jak można zmobilizować dla „sprawy” tysiące ludzi przy użyciu telefonu. Niestrudzoność Júlii Rajk i jej starania o jak najszerszy rozgłos o ponownym pogrzebie jej męża 6 października 1956 roku sprawiły, że wydarzenie to stało się psychologiczną próbą sił przed rewolucją 1956.

5 Jeden z najstarszych węgierskich cmentarzy, miejsce pochówku słynnych Węgrów, m.in. Lajosa Kossutha, Lajosa Batthyányego czy Endre Adyego [przyp. tłum.] 
4 listopada 1956 roku, gdy wznowiono radziecką interwencję, Rajk razem z Imre Nagyem, premierem rewolucji 1956 i członkami jego gabinetu, poprosiła w ambasadzie Jugosławii o azyl polityczny. Jednak potem została z nimi uprowadzona do Rumunii przez sowietów. Spędziła tam dwa lata, mogła powrócić na Węgry w październiku 1958 roku. Stopniowo stała się kluczową osobą w ruchu oporu, domagającym się rehabilitacji Nagyego i jego towarzyszy. Po 1958 roku stała się Tą Júlia, człowiekiem-instytucją, broniącą słabych przed tymi, którzy nadużywali swojej władzy, negocjującą z kierownictwem partii, chroniąc antykomunistycznych intelektualistów. Stworzyła pierwszą organizację pozarządową na Węgrzech po zakazie tworzenia stowarzyszeń w 1951 roku: schronisko dla psów; organizowała także zbiórkę podpisów pod Kartą 77 i walczyła przeciw zaostrzeniu przepisów antyaborcyjnych. Odszkodowanie, jakie otrzymała po śmierci męża przeznaczyła na stworzenie funduszu wspierającego uzdolnionych studentów - w czasach gdy indywidualna dobroczynność nie była ceniona. Pracowała jako archiwistka wWęgierskim Archiwum Narodowym do przejścia na emeryturę. Zmarła na raka w Budapeszcie w 1981 roku.

\section{Ramy i źródła dla opisów historii komunistek}

Biografie kobiet, które działały w ruchu komunistycznym przed II wojną światową można pisać, używając różnych ram, w zależności od wnikliwości i zamiarów danego historyka/historyczki i umiejętności konstruowania politycznej podmiotowości związanej z płcią kulturową.

Jako że kobiet, które zajmowały ważne pozycje w „prawdziwej polityce”, było niewiele, opisuje się je albo jako bezwzględne i przenikliwe manipulatorki, albo jako ofiary, które wierzyły w ideę (np. komunizm), ale dały się zwieść przez antydemokratyczne działania, chociaż miały dobre intencje, aby walczyć o prawa kobiet ${ }^{6}$. Analizując pamiętniki i wywiady z kobietami węgierskimi działającymi w nielegalnym ruchu komunistycznym przed 1945 rokiem, stwierdziłam, że były one pomijane lub zamykane w ramach narracyjnych bez kwestionowania patriarchalnych struktur?.

6 N. Funk A Very Tangled Knot: Official State Socialist Women's Organizations, Women's Agency and Feminism in Eastern European State Socialism, "European Journal of Women's Studies” 2014 No. 4, s. 344-360.

7 A. Pető A Missing Piece: How Hungarian Women in the Communist Nomenclatura are not Remembering, Eastern Europe: Women in Transition, ed. by I. Grudzińska-Gross, A. Tymowski, w: Eastern European Culture, Politics and Societies 3, Peter Lang, Frankfurt 2013, s. 145-155. 
Opisując życie Júlii Rajk, miałam do wyboru różne możliwości. Zdecydowałam się użyć jako ramy narracyjnej jej walkę o swoje nazwisko, nawiązując do feministycznych postulatów dotyczących prawa do własnej tożsamości ${ }^{8}$. Polityczny sukces Rajk i jej wpływ mają swoje źródła w jej ewidentnie niepolitycznym sposobie wyrażania się. Wypowiadała się publicznie jako matka i żona, podważając rozczarowujący polityczny dyskurs stalinowskiej nowomowy. Júlia była też pierwszą praktyczką " antypolityki", która stworzyła odrębne instytucje w sferze półpublicznej: prowadziła salon dyskusyjny podejmujący zarówno tematy związane z polityką, jak i najnowsze plotki; schronisko dla psów, zabierała dzieci uwięzionych towarzyszy do cukierni itp.' Zinstytucjonalizowała nieformalność, współtworzyła nowe instytucje - tak jak szkoła w Rumunii, którą stworzyło środowisko związane z Imre Nagyim (1956-1958), autokarowe „wycieczki Júlii” na „Zachód”, jej formą oporu były rozmowy. Na pierwszy rzut oka wygląda to jak wspaniała historia życia, która będzie łatwa do opowiedzenia. Jednak jako biografistka spotkałam się z pewnymi wyzwaniami.

Pierwszym problemem są zawsze źródła. Dla piszącego biografię rodzina jest strażnikiem informacji. Syn Rajk, znany architekt, scenograf i ważny członek opozycji demokratycznej, ma prawo do milczenia i wyboru, czym chce podzielić się z badaczem. Jego wybiórczość zmieniła się przez piętnaście lat. Rajk nie była intelektualistką, nie zostawiła wiele źródeł pisanych, tylko ręcznie spisane zeznania w więzieniu. Jej autozapisem była działalność polityczna. Nie miałam dostępu do jej prywatnego archiwum - syn wspomniał, że ma na strychu skrzynię pełną papierów, jednak nie chciał jej otwierać.

Drugi problem to komunistyczny ikonoklazm. Mąż Júlii, László Rajk był bezwzględnym i utalentowanym komunistą, który bez zawahania niszczył pozostałości demokratycznych struktur w węgierskim społeczeństwie, wysyłał polityków opozycji do więzienia lub gułagu. Źródła dotyczące ich obojga, protokoły z procesu, zapisy inwigilacji zostały zniszczone. To także miało na nią wpływ.

Trzeci problem to fakt, że Júlia nie była miłą, przyjazną osobą - raczej trudna w obyciu, surowa, w publicznych dyskusjach zdawała się uważać,

8 D. Riley Am I That Name?: Feminism And the Category of,Women' in History, MacMillan, London 1988.

9 A. Petö, J. Szapor Women and "the Alternative Public Sphere": toward a new definition of women's

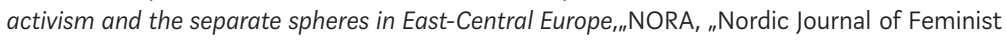
and Gender Research" 2004 No. 3, S. 172-182. 
że wie wszystko lepiej. Podczas pisania jej biografii najczęściej używanym przeze mnie rodzajem źródła była historia mówiona, a tematem wywiadów jest bardziej zmiana ram narracyjnych i samoprezentacji przeprowadzającego wywiad niż samej pary bohaterów. Teraz wszystkie te osoby nie żyją, więc nie jest możliwe ponowne zadanie im pytań.

Czwarty problem to ramy narracyjne. Zazwyczaj historie życia kobiet sa opowiadane poprzez Bildungsroman - pokazują, jak bohaterka staje się coraz bardziej zdecydowana i przekonana do ideologii. Historia Júlii Rajk powinna być prezentowana w inny sposób. To nie jest Bildungsroman, historia rozwoju rozpoczynająca się od dziecięcych doświadczeń - jej socjalizacji - w lewicującej rodzinie należącej do klasy pracującej, z ojcem pod obserwacją policji za udział w krótkiej rewolucji komunistycznej w 1919 roku. Júlia była zdecydowaną socjaldemokratką, członkinią partii komunistycznej (początkowo nielegalnej), pozostała nią do śmierci w 1981 roku. Zawsze używała swojej mocy - mocy wdowy - jako ofiara procesów pokazowych, aby uzyskać to, co chciała - od rehabilitacji męża po paszporty dla dysydentów. Jest to raczej Unbildungsroman - proces nauki i dostosowywania się do zmieniających się okoliczności politycznych. Bohaterka opowieści była nielegalną komunistką, potem stała się żoną, następnie wdową i matką. Trudno także zmieścić jej historię w ramy stworzone przez feminizm po 1989 roku - była przede wszystkim zainteresowana problemami wolności i demokracji, a nie tematami, które teraz zalicza się do problematyki kobiecej, jak przemoc domowa lub prawa LGBTQIA. W ciagu ostatnich 16 lat zaszły duże zmiany, odnośnie do źródeł i ram narracyjnych, które wpływają na to, jak można opisywać historię Júlii Rajk.

\section{Nowe źródła}

W ostatnich latach dostęp do pierwotnych źródeł stał się z jednej strony łatwiejszy, ale pod innymi względami trudniejszy. Na pewno w ciągu minionych 16 lat więcej materiałów pojawiło się online - to następstwo cyfrowej rewolucji. Badacze nie muszą już podróżować do odległych archiwów. Gdy wyszukałam nazwisko Júlii Rajk w Google, na moim ekranie pojawiły się dzienniki, gazety, dokumenty, o których nie wiedziałam, że o niej wspominały. Postęp technologiczny będzie mieć ogromny wpływ na naukę. Pierwotne źródła, które zostały zdigitalizowane, będą używane podczas badań, tak jak w przypadku tego artykułu, natomiast niezdigitalizowane, jak większość węgierskich dzienników i gazet publikowanych w ostatnich dekadach, zostaną pominięte i zapomniane przez badaczy. 
Gdy robiłam kwerendę do mojej książki, pod koniec lat 9o., dosłownie przesiedziałam w archiwach lata. Teraz nie byłoby to fizycznie możliwe, gdyż węgierski rząd zaplanował przeniesienie kolekcji narodowych archiwów z historycznej dzielnicy zamkowej do nowego archiwum, które ma być zbudowane w nieznanej przyszłości. W związku z przenosinami badania dotyczące dokumentów powstałych po 1945 roku nie są obecnie możliwe, nie jest znana data, gdy znów staną się dostępne. Można używać Internetu i zdigitalizowanych źródeł, ale dotyczy ich specyficzna polityka selektywności. Zasoby internetowych wydań największych dzienników międzynarodowych, takich jak „Spiegel” czy „La Repubblica” są dostępne online i można w nich wyszukać doniesienia odnośnie do Júlii Raj $\mathrm{k}^{\mathbf{1 0}}$. Katalog rzeczowy Open Society Archives także został zdigitalizowany, więc nie trzeba już spędzać czasu w tamtejszej przytulnej czytelni. Jednak najważniejsze źródła po węgiersku, zarówno archiwa, jak i źródła wtórne, nie zostały poddane digitalizacji, czasem są w ogóle niedostępne, co utrudnia badania.

Kolejnym aspektem cyfrowej rewolucji jest duża liczba zdjęć dostępnych w Internecie. Fotografie, do których nie miałam dostępu podczas kwerendy, teraz pojawiają się tuzinami w wyszukiwaniu w Google. Tymczasem piętnaście lat temu, jeśli właściciel zdjęć udostępnił mi cenne odbitki ze swojej kolekcji, uważałam to za ogromne szczęście i cieszyłam się z zaufania. Spośród nowych fotografii dostępnych online większość została zrobiona podczas ponownego pogrzebu László Rajka, 6 października 1956 roku. Są to zdjęcia prywatne i prasowe, jako że było to najliczniej fotografowane wydarzenie lat 50. i późniejszych.

László Rajk Jr., idąc z duchem czasu, założył swoją stronę internetową. Opublikował tam zdjęcia, którymi nie podzielił się ze mną, gdy prowadziłam badania do książki. Witryna syna Júlii Rajk pokazuje jego rodziców i ich pracę w równorzędny sposób. Zdjęcia, których wcześniej nie widziałam, pokazują matkę Júlii, ją samą z rodziną na wycieczce w latach 30., jest też jedyne zdjęcie rodziny Rajk razem: Júlia trzyma w beciku niemowlę - małego László, uśmiechnięty ojciec stoi za nimi, patrząc na chłopca z dumą. Intymność, zwyczajność i ikonografia tego zdjęcia: matka z dzieckiem i dumny, obserwujący ich ojciec - ta scena w jakiś sposób nie pasuje do wartości wyznawanych przez parę - komunistycznej równości.

10 "L'Espresso", 4 listopada 1956, „La Repubblica”, 15 kwietnia 1992, „Der Spiegel”, 24 października 1956. 
Najbardziej ekscytującym zadaniem związanym z pisaniem książki jest wybór okładki. Wybrałam oficjalne zdjęcie państwa Rajk - stoją na nim na podium podczas święta żniw i klaszczą. Na oryginalnej fotografii po lewej stronie od László stoi piękna kobieta - zawsze był otoczony pięknymi kobietami. Wydawca podczas tworzenia okładki zdecydował się wyciąć (za pomocą programu Photoshop) tę osobę z fotografii. Recenzje, artykuły, wywiady dotyczące książki były potem często publikowane z tym przerobionym zdjęciem jako autentycznym. Fenomen fałszywej nauki i fałszywych zdjęć nie jest czymś nowym, ale powstaje trudne pytanie - kim była ta kobieta, którą dla feministycznej biografii wycięto ze zdjęcia i komu grozi zniknięcie na zawsze z historiografii.

Rewolucja cyfrowa wprowadziła nowy element do polityki selekcji źródeł historycznych. Tylko niektóre źródła stały się dostępne online - w zależności od zajmowanej pozycji i zasobów danej instytucji lub osoby. Cyfrowe obywatelstwo jednym daje silniejszą pozycję, a drugich osłabia w zależności od tego, czy dana instytucja ma środki na digitalizację i publikację online. Júlia formalnie nie zajmowała ważnej pozycji, więc źródła o niej nie są dostępne. Nawet po cyfrowej rewolucji jej historię reprezentują inni.

Rewolucja cyfrowa nie tylko sprawiła, że pojawiły się nowe, nieoczekiwane źródła, ale także ekscytujące publikacje. W 2012 roku otrzymałam e- mail od mojego drogiego przyjaciela Padraica Kenneya, który zasugerował, że powinnam pomóc jego doktorantce, która przygotowuje swoją pierwszą książkę o kobietach w więzieniach w czasie komunizmu. Wkrótce w mojej skrzynce pojawił się e-mail od Anny Muller z prośbą o źródła dotyczące życia prywatnego i doświadczeń (ego documents) do publikacji, której kuratorem miał być polski Instytut Pamięci Narodowej - IPN. Odpowiedziałam, że myślę, że wszystkie dokumenty dotyczące Júlii zostały już opublikowane lub są dostępne na stronie internetowej jej syna. Obiecałam to z nim potwierdzić. Skontaktowałam się z nim i znów okazało się, jak bardzo się myliłam - pojawiły się nieoczekiwane dokumenty z prywatnego archiwum László Rajka; mają być opublikowane w Warszawie, po polsku. To prawdopodobnie był czas, gdy skrzynia ze strychu została otwarta.

László Rajk udostępnił dla polskiego projektu trzy listy wysłane przez Júlię z jej zesłania do Rumunii - nie podzielił się nimi ze mną, gdy pisałam książkę. W zestawie zeskanowanych dokumentów, które wysłał za moim pośrednictwem do Warszawy, było jeszcze bardzo poruszające zdjęcie. Przedstawia László Rajka Juniora w sierocińcu, ma ręcznie napisany komentarz Júlii, że pochodzi z grudnia 1949 roku, siedem miesięcy po uwięzieniu jego rodziców, już po śmierci ojca. Júlia uznała także za ważne dopisać na odwrocie fotografii 
ołówkiem, że miała ją ze sobą przez cały pobyt w więzieniu. Zdjęcie otrzymała od Ákosa Pála, starej daty pułkownika policji politycznej, który brał udział w przygotowywaniu procesu Rajka i popełnił samobójstwo, gdy w 1951 roku aresztowano Jánosa Kádára. Łatwo zrozumieć, że syn nie chciał dzielić się tym zdjęciem z szerszą publicznością, więc nie jest dostępne na jego stronie internetowej. Co sprawiło, że zgodził się udostępnić je w książce, która ma się ukazać w Polsce, po polsku? Do publikacji wciąż nie doszło, w wyniku polityki IPN, który na początku zamówił książkę. Po latach ciszy IPN zgodził się na druk w innym wydawnictwie, ale dopiero w 2018 roku. Z jednej strony nowe, ekscytujące źródła zostały ujawnione podczas prac nad książką, której kuratorem miał być kontrowersyjny wtedy państwowy instytut badawczy. Z drugiej - źródła te pozostają nieopublikowane, w wyniku nieliberalnych zmian w Polsce, podczas gdy odkryto je w ramach tych nieliberalnych zmian.

\section{Nowe ramy}

Kolejne pytanie dotyczy tego, w jaki sposób w ubiegłych latach zmieniły się ramy narracyjne, w których opowiada się historie życia kobiet. Co wydarzyło się przez szesnaście lat od momentu publikacji mojej książki w 2001 roku? Czy książka kwestionująca kanony przyczyniła się do stworzenia nowego kanonu? Czy wnioski z mojej biografii stały się integralną, niezbędną częścią historiografii, ograniczonej przez ramy narodowe? Czy prezentacja gender jako kategorii analizy doprowadziła do „epistemologicznej zmiany” w historiografii"1? Odpowiedź brzmi „nie” - książka o Júlii Rajk nie stała się częścią historycznego kanonu, bohaterka nadal jest zaszufladkowana w narracjach historycznych jako wdowa po László Rajku². Jednak w ciągu ostatnich piętnastu lat doszło do dwóch niespodziewanych zmian w kontekście, w którym opisuje się historię kobiet ${ }^{13}$. Pierwsza to konserwatywna rewolucja herstory,

11 A. Pető Eastern Europe: Gender Research, Knowledge Production and Institutions, „Handbuch Interdisziplinäre Geschlechterforschung", 2018 No. 1-11, DOI 10.1007/978-3-658-12500-4_153-1.

12 Zob. tekst mojej przemowy po otrzymaniu nagrody ALLEA 2018 opublikowany po węgiersku: Germaine és Júlia. Párhuzamos történetek az európai históriában, „168 óra” 7 June 2018, s. 42-44. і ро bułgarsku: Паралели в европейската история, "Literaturen vestnik" 27 June 2018 No. 9 .

13 A. Pető Changing Paradigms of Writing Women's History in Post-Communist Europe, Парачовешкото: грация и гравитация- сборник в чест на проф. Миглена Николчин. The Parahuman: Grace and Gravity. In honour of prof. Miglena Nikolchina, ed. by K. Spassova, D. Tenev, M. Kalinova, Sofia University, Sofia 2017, s. 280-289. 
która sprawiła, że Júlia Rajk stała się dostrzegana, jednocześnie wzrosło też zainteresowanie feminizmem w komunistycznym ruchu kobiecym, co paradoksalnie przyczyniło się do pomijania jej historii.

Ta pierwsza zmiana, związana z ideą herstory, według której kobiety mają przestać być nieobecne w historii. Jednak ramy, w jakich pisze się o kobietach w dziejach, to cierpienie, poświęcenie i bycie ofiarą, a nie działanie i podmiotowośćc ${ }^{14}$. Ta nowa szkoła w historiografii jest dla nieliberalnego państwa sposobem na zawłaszczenie dla swoich własnych celów polityki pamięci o wydarzeniach historycznych. Kobiety stopniowo stały się akceptowanym i wartościowym tematem badań historycznych, ale bez kwestionowania tradycyjnych ram. Tematyka taka jak więźniarki polityczne podczas komunizmu zajęła ważne miejsce w pracach badawczych instytucji specjalizujących się w badaniach nad zbrodniami komunizmu - ich celem jest sprawienie, żeby kobiety były dostrzegane w historii. Historia życia Júlii Rajk właściwie mogłaby zostać umieszczona w takich ramach - opisywana jako opowieść o cierpieniu i opresjach podczas komunizmu. Dostrzeganie kobiet jest także celem feministycznej historiografii. Jednak narracja skoncentrowana na narodzie utrzymuje swój paradygmat niezależnej wspólnoty, a kobiety są uważane za jedną z wielu grup, za dodatek. W ten sposób Júlia pozostaje także poza tym nowo utworzonym kanonem.

Druga zmiana to dyskusja naukowa prowadzona w ramach gender studies - czy „komunistyczny feminizm” w ogóle istniał. W podsumowującym dossier Aspasia, The International Yearbook of Central, Eastern, and Southeastern European Women's and Gender History tomy 6 i 7 skupiają się na wymienieniu osiągnięć. To zrozumiałe, że z powodu rozczarowania neoliberalną polityką krytyczni intelektualiści podejmą próbę ponownej oceny feminizmu powiązanego z państwem, jaki istniał w czasach komunizmu (ale także w czasach wcześniejszych). Takie badania koncentrują się na różnych organizacjach kobiecych o zasięgu krajowym i międzynarodowym. Historia Júlii Rajk nie pasuje do takiej agendy badań, mimo że była ona zadeklarowaną komunistką. Współczesne debaty o nostalgicznej prezentacji historii kobiet w czasie komunizmu przyczyniają się do autogettoizacji w momencie historycznym, gdy krytyczna analiza progresywnej tradycji i praktyki jest najbardziej potrzebna.

14 A. Pető Roots of Illiberal Memory Politics: Remembering Women in the 1956 Hungarian Revolution, "Baltic Worlds" 2017 No. 4, S. 42-58. 


\section{Wnioski}

Historia życia Júlii Rajk ilustruje złożoność płci kulturowej i komunizmu w kontekście budowy politycznej podmiotowości kobiet i pokazuje, jak dużym wyzwaniem dla kobiecych historii jest populizm. Paul Frosh zwrócił uwagę na „znaczenie świadectwa dla współczesnych związków między osobistym doświadczeniem, wiedzą, którą można się dzielić (shareable knowledge), i reprezentacji publicznej"15. Historia życia Júlii Rajk w 2001 roku była wiedzą, którą można się dzielić. W 2018 roku kobieca herstory i antykomunizm uwydatniają niektóre części jej historii, ale pomijają inne. Mimo dużej liczby źródeł dostępnych online, jej historia jest ograniczona do strony internetowej jej syna i napisanej przeze mnie biografii.

Niedawno zostałam poproszona o wygłoszenie wykładu o Júlii Rajk w koledżu noszącym imię László Rajka. Społeczność Uniwersytetu Korwina w Budapeszcie była pod presją nowego, konserwatywnego rządu, aby zmienić nazwę podlegającego mu koledżu, zgodnie z planem eliminacji nazw ulic i instytucji związanych z ruchami lewicowymi. Podczas dyskusji odnośnie do tej kwestii padła propozycja, aby László zastąpić Júlią Rajk i w ten sposób z jednej strony wyjść naprzeciw oczekiwaniom rządu, a z drugiej - ograniczyć wydatki na nowe pieczątki i druki. Jednak pomysł został odrzucony przez władze koledżu większością głosów. Argumentowano, że - co oczywiste - Júlia Rajk także była komunistką, a ten fakt był dla rządu najważniejszym problemem. Podniesiono także argument, że pomysł mógłby zostać uznany za żart.

Przełożyła Dorota Boni Menezes

15 P. Frosh Telling Presences: Witnessing, Mass Media, and the Imagined Lives of Strangers Critical Studies, "Media Communication" 2006 No. 4, S. 267. 


\section{Abstract}

\section{Andrea Pető}

CENTRAL EUROPEAN UNIVERSITY (HUNGARY)

HUNGARIAN ACADEMY OF SCIENCES

Revisiting the Life Story of Julia Rajk

Pető discusses the difficulties of writing the life story of Júlia Rajk, the wife of László Rajk (1909-1949), a leading Hungarian communist. She argues that while the digital turn makes new sources such as newspaper articles and photos visible and accessible, the illiberal state's politics of commemoration uses herstory as a tool of "mnemonic security" and places Júlia Rajk's life outside the canon.

\section{Keywords}

life story, digital turn, women's history, herstory turn, Hungary, gender history, women in politics 